\title{
Performance of Total Haemocyte Count and Survival Rate The Tiger Prawn Penaeus Monodon Fabricius Juvenile Rearing at High Density
}

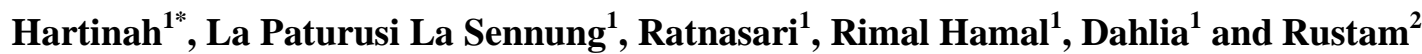 \\ ${ }^{1}$ Lecturer of Aquaculture Department, Pangkep State Polytechnic of Agriculture, South Sulawesi \\ ${ }^{2}$ Lecturer of Departement of marine science, Faculty of Fisheries and marine science. Universitas Muslim Indonesia \\ *Email: tinatayibu@gmail.com
}

\begin{abstract}
Hartinah, La Paturusi La Sennung, Ratnasari, Rimal Hamal, Dahlia and Rustam. 2017. Performance of Total Haemocyte Count and Survival Rate The Tiger Prawn Penaeus Monodon Fabricius Juvenile Rearing at High Density. Aquacultura Indonesiana, 18 (1): 9-14. High density is one of the common consequences of intensive shrimp culture. High density can induce stress on the shrimp. Nonetheless, stress is not always harmful. In limited period, stress can trigger metabolism process and the hormonal system of the body. This study aimed to determine how high-density rearing causes stress on juvenile shrimp. The experiment consisted of three different density treatments, 60,90 and 120 tiger prawn juveniles $/ \mathrm{m}^{2}$ with two different weight groups, 3 to $10 \mathrm{~g}$, and 11 to $16 \mathrm{~g}$ as test animals. Each treatment with 3 replications, and 2 stocks were provided for treatment $\mathrm{A}, \mathrm{B}$, and $\mathrm{C}$ respectively (the stock was prepared to substitute the test animals at hemolymph sampling). Total Haemocyte Count (THC) was the main parameter used as a reference in assessing the response of tiger prawn juveniles to hight density. Based on the 3 treatments densities tested, the results showed that THC of the juvenile tiger prawns reared at 3 densities increased up to $24 \mathrm{~h}$ observation and decreased at $36 \mathrm{~h}$ observation. In fact, THC of the shrimp at the highest rearing density of 120 juveniles $/ \mathrm{m} 2$ increased, which is one of the alleged treatment of tiger prawn juveniles tried to increase the tiger prawn's body defence. But the decline in THC was observed in the lowest rearing density of $60 \mathrm{shrimps} / \mathrm{m}^{2}$, in which the treatment did not cause stress on the tiger prawns in the lower weight group of 5 to $10 \mathrm{~g}$ (treatment $\mathrm{A}$ ). In contrast, THC of the tiger prawn in the medium and highest rearing density (treatment B and C) drastically declined due to stress on tiger prawn juvenile and led to the tiger prawn dead. However, it is assumed that the tiger prawn juvenile that can adapt to the stressful condition, stress may become a stimulus that can trigger moulting, which is olso known as an indicator of growth.
\end{abstract}

Keywords: High-density rearing; Survival rate of tiger prawn juvenile; Total Haemocyte Count

\section{Introduction}

The environment, pathogens, and shrimp are three components which cannot be separated and even eliminated from aquaculture process. Those three components are bound together in the aquaculture process. For instance, pathogens can only be minimized to promote a better environment for maintaining optimum physiological condition of shrimp farming. In order to maintain the optimum environment for high black tiger prawn productivity, intensive aquaculture technology has been well implemented in aquaculture. The characteristics of intensive aquaculture are high density $(\geq 30$ individuals $\left./ \mathrm{m}^{2}\right), 20-60 \mathrm{PL} / \mathrm{m}^{2}$ and relying on artificial feed as a nutrient supply (FAO, 2006)

Studies on the rearing density of shrimp in the ponds have been well-documented (Allan and Maguir, 1992, Primavera and Apud, 1994, Salama, 2005, Mangampa et al., 2008 and
Supomo, 2009). Nonetheless, the growth performance and survival rate are commonly two factors used as a variable indicator to determine the physiological responses of the cultured species, in which growth performance is an indicator of long-term stress. The management of shrimp farming merely refers to the monitoring of these indicators. In case of extreme conditions in long-term for example high density, the tiger prawn died before the prevention. In addition, Wolffrom (2004) stated that the interaction between animals, handling, transportation, and environmental (temperature, oxygen, $\mathrm{pH}$, chemicals) are common stressor observed in the aquaculture. Indicator performance of total haemocyte count can detect earlier stress level before death.

Due to high rearing density, shrimp is required to adapt to the condition of particularly low dissolved oxygen level, less space and the interaction among the animals in the ponds. The 
interaction each other of tiger prawn juvenile in tanks on the high density should be stress because of space competition. feed and oxygen are optimal conditions. It takes a large amount of energy of shrimp for maintaining the optimum physiological condition, leads to stress and negatively affects the fish haemocyte cell composition. Haemocyte of the crustacean is identified as defense indicator, which has high phagocyte activity (Van de Braak, 2002). Perazzolo et al. (2002) reported that Total Haemocyte Count (THC $=$ number of haemocyte $)$ and Total Serum Protein $(\mathrm{PC}=$ total protein haemolymph $)$ are the most sensitive physiological response to stress conditions in shrimp (Farfantepenaeus paulensis). Furthermore, Wolffrom (2004) stated that three levels of the stress responses, including primary, secondary, and tertiary responses. The primary response of fish is the release of catecholamines and corticosteroid, while the secondary response is a direct reaction of haemolymph and hormones, and the tertiary response is a longterm response, which affects growth, reproduction, and immune responses of the fish.

Based on the previous studies, high rearing density can lead to stress. As a result, it alters the composition of the haemocyte cells in the tiger prawn's body. However, the mechanism of this relationship is very complex and requires further studies. Therefore, the aim of this study is to investigate the effect of high rearing density on the total haemocyte count of tiger prawn (Penaeus monodon).

\section{Materials and Methods}

\section{Location and Time of Activity}

The research was carried in a Seed Fish Hatchery Laboratory and Laboratory Disease Agriculture Polytechnic, respectively in Pangkep, South Sulawesi, during May to early June 2016.

\section{Research Design}

The rearing densities of tiger prawn juvenile were at 60,90 and $120 \mathrm{shrimp} / \mathrm{m}^{2}$ equivalent to density of 10,15 and 20 shrimp/tank $(40 \times 35 \times 35 \mathrm{~cm})$. The tanks were filled with 52.5 liters of water. Each treatment had three replicates, and two stocks were provided for each treatment (five shrimp per tank). One stock was prepared as replacement stock when conducting sampling and observations of the shrimp hemolymph. The shrimp was daily fed during the 20-day of trial.

\section{Hemolymph preparation}

The number of haemocyte was calculated by taking hemolymph on the second segment of the ventral abdominal part of the hemocoel using a syringe needle. $1 \mathrm{~mL}$ of 27 gauge hypodermic, which contained anti-coagulant $(0.01 \mathrm{M}$ tris$\mathrm{HCl}, 0.25 \mathrm{M}$ sucrose, $0.1 \mathrm{M}$ Sodium citrate; at $\mathrm{pH}$ 7.6) was used using haemocytometer $(0,1$ $\mathrm{mm}$ ) under a light microscope with $1000 \times$ magnification.

\section{Data analysis}

The number of haemocyte was counted by counter (Gopinath and George, 2000). Furthermore, haemocyte was calculated using the equation:

$$
\Sigma=\mathrm{P} \times \mathrm{N} \times 103 \times 25 \text { cells } / \mathrm{mL}
$$

Where:

$\mathrm{P}=$ Number of small squares in a haemocytometer (16)

$\mathrm{N}=$ Average number calculated haemocyte boxed in some small

$10^{3}=$ Volume of sample in a large box (if using a $0.1 \mathrm{~mm}$ depth haemocytometer)

$25=$ Number of squares in a haemocytometer

\section{Survival rate $(S R)$}

Survival rate (SR) was calculated using the equation described by Effendie (2002).

\section{Water quality}

Water quality monitoring was conducted for supporting data, including temperature, salinity, DO and $\mathrm{pH}$ water.

\section{Result}

The results of the haemocyte observation on tiger prawn juveniles during the study are shown in Figure 1. Figure 1 indicated that the haemocyte of tiger prawn juveniles of different body weights increased after being stocked at different densities for $24 \mathrm{~h}$, and the number haemocyte of tiger prawn juvenile declined in rearing density of $60 \mathrm{shrimp} / \mathrm{m}^{2}$, which was recorded at $36 \mathrm{~h}$ of observation. The decline that occurred at densities of 90 and $120 \mathrm{shrimp} / \mathrm{m}^{2}$. 


\section{Survival Rate}

The results showed that the results tiger prawn juveniles during the study are shown in Figure 2. That the rearing density of tiger prawn juveniles at 60 shrimp $/ \mathrm{m} 2$ reached the homeostasis condition at 24-hof monitoring and the intervention this density did not cause any stress. Otherwise, when the tiger prawn reared at density of 90 and 120 shrimp/m2; the intervention caused stress on tiger prawn juveniles, led to the tiger prawn dead (Figure 2).

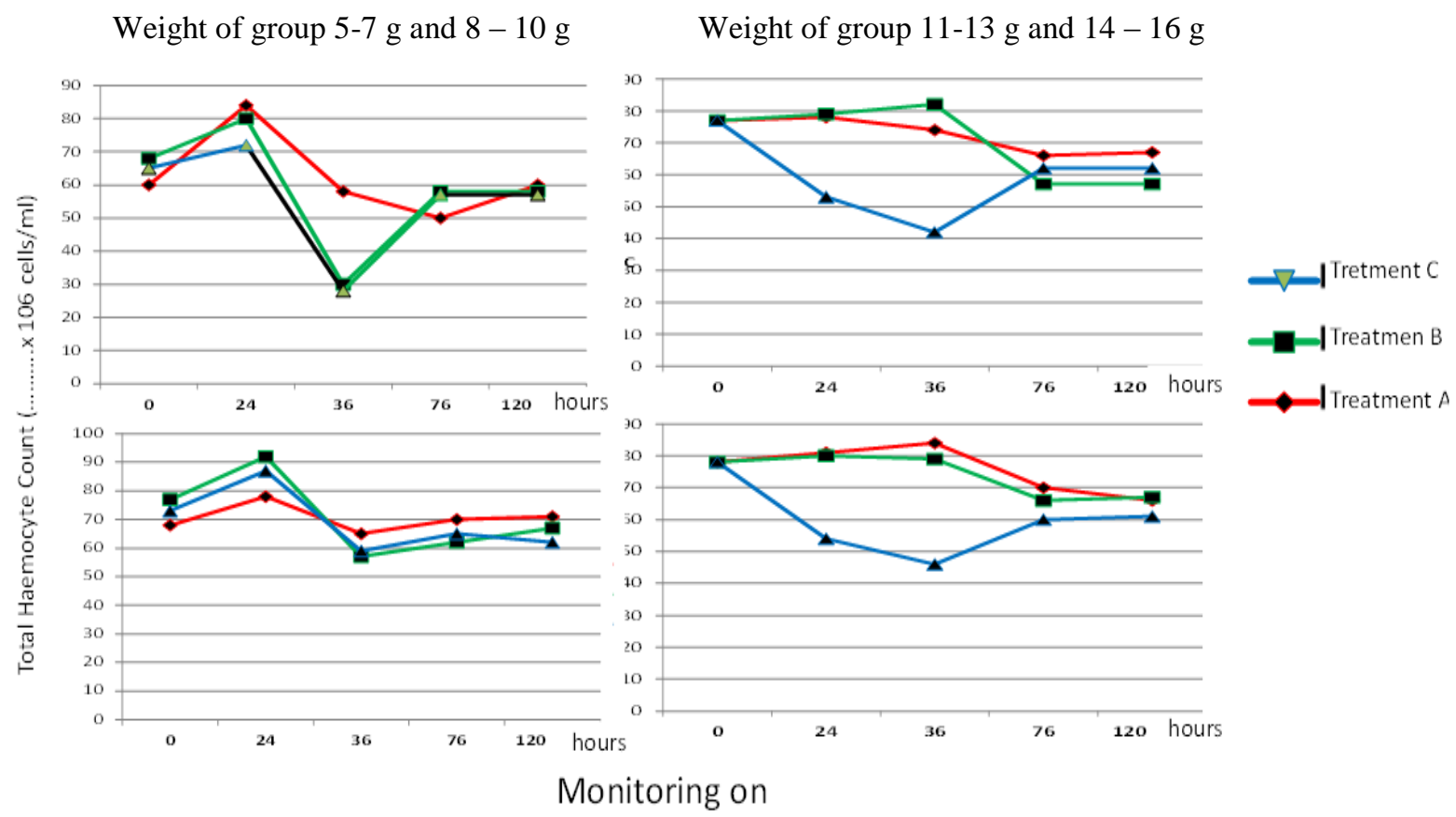

Figure 1. The relationship of the number's haemocyte $\left(\ldots \times 10^{6}\right.$ cells $\left./ \mathrm{mL}\right)$ of tiger prawn juvenile reared at different weight and densities (Treatment $A=60$ shrimp $/ \mathrm{m}^{2}$, treatment $B=90$ shrimp $/ \mathrm{m}^{2}$, treatment $\mathrm{C}=120 \mathrm{shrimp} / \mathrm{m}^{2}$ )
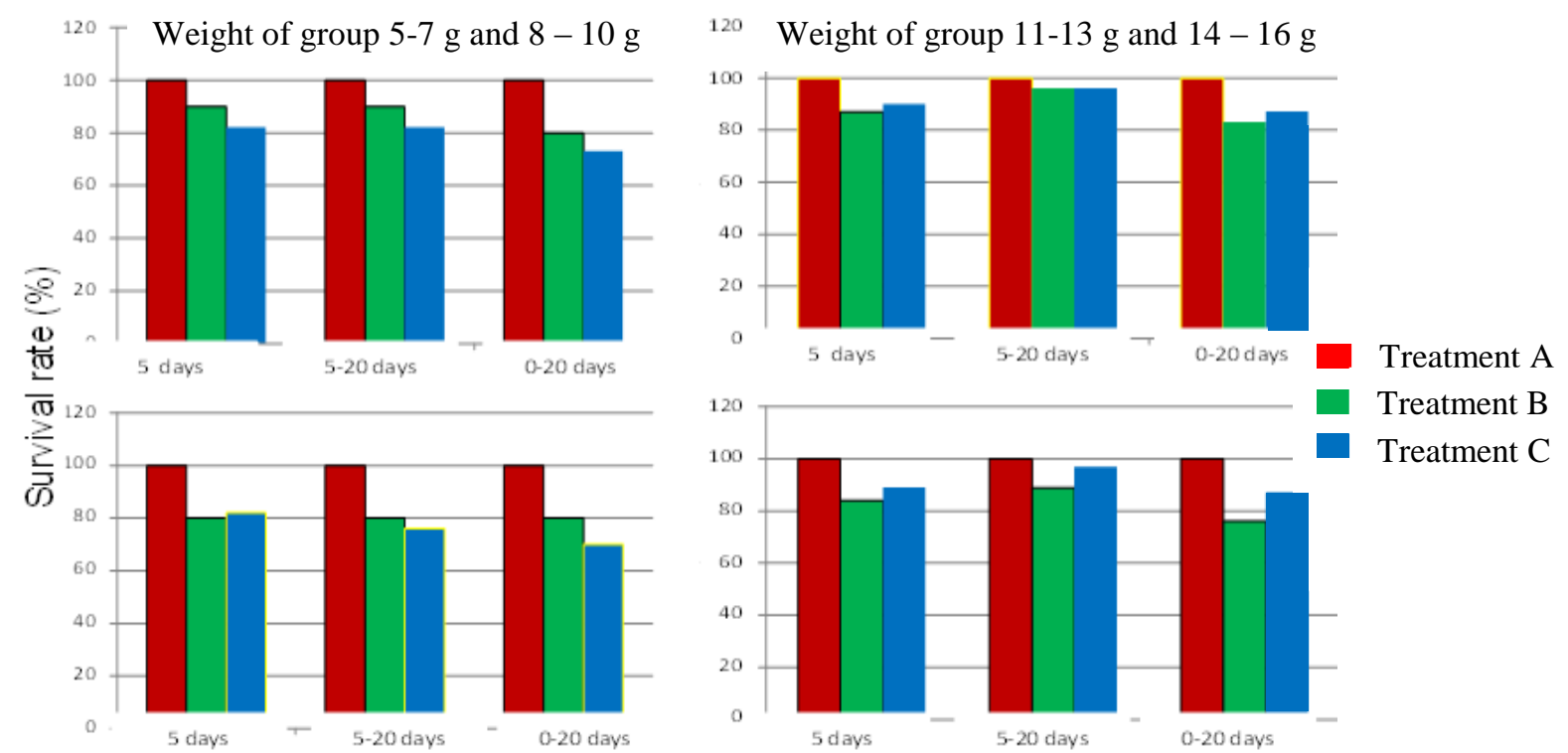

Days of monitoring

Figure 2. Histogram survival rate of juvenile tiger prawn for 5 and 20 days of monitoring, weight of 3 $-6 \mathrm{~g}, 7-10 \mathrm{~g}, 11-14 \mathrm{~g}$ and $15-18 \mathrm{~g}$, each treatment (Treatment $\mathrm{A}=60 \mathrm{shrimp} / \mathrm{m}^{2}$, treatment $\mathrm{B}=90$ shrimp $/ \mathrm{m}^{2}$, treatment $\mathrm{C}=120$ shrimp $/ \mathrm{m}^{2}$ ). 


\section{Water Quality}

The results of the range of water quality parameters were measurements during the study are shown in Table 1.

Table 1. Water Quality Parameter in the Present Study

\begin{tabular}{lc}
\hline \multicolumn{1}{c}{ Parameter } & $\begin{array}{c}\text { The range of water } \\
\text { quality parameters }\end{array}$ \\
\hline Water temperature $\left({ }^{\circ} \mathrm{C}\right)$ & $28-30$ \\
$\mathrm{pH}$ & $7.12-7.9$ \\
$\mathrm{DO}$ & $6.2-6.6$ \\
Ammonia (ppm.) & $0.003-0.029$ \\
Salinity (ppt.) & 20 \\
\hline
\end{tabular}

The ranges of water quality parameters are still within the optimum range for the life of tiger prawn juvenile, as recommended by Buranajitpirom et al. (2010), Lemonnie et al. (2004), Liu (1989), Re and Díaz (2011) and Rollo et al. (2006).

\section{Discussion}

The existence of space competition and interaction friction between animals in rearing high density is a signal received by the Central Nervous System (CNS) of tiger prawn juvenile that became alarm, it is interpreting the signal, then stimulated the secretory neuro cells to produce neurosecretory cell hormones that can stimulate or inhibit the $\mathrm{x}$ organs and sinus glands in the eye stalk. Furthermore, the x-organ can control other organs around it, one of which produces the hormone 5.6 dihydroptritamine, 5 hydroxy triptamine and 6 hydroxy triptamins that control neurogeni activity in the heart that regulates heart rate, which can trigger conduction of the heart (Lockwood, 1968 and Smith, 1982 ). As a result the contraction of the heart increases, as homeostasis are developed because of anxiety experienced by tiger prawn juvenile on new environment and intervention of hight density treatment. The sympathetic reactions in the nervous system caused by increased heart contraction eventually increase respiration where it is suspected that tiger prawn juveniles breathe faster which triggers higher blood pressure to supply oxygen demand. The effect of increased heart contraction was evidenced by the increasing THC of tiger prawn juvenile at $24 \mathrm{~h}$ in all treatments. Increasing THC will drain energy to the extent of excessive homeostasis to neutralize the contraction of the heart to normal. Increased THC is one indicator of increased endurance.

The results showed that after being stocked at different densities for $24 \mathrm{~h}$, indicates that shrimp physiologically respond to new environments (high density) by improving their body defenses. increased body defense is known because THC increases. According Direkbusarakom and Danayadol (1998) that the increase in THC is one indicator of increased body defense crustaceans. Furthermore, it was stated that hemolymph identified as an indicator of the immune system of the shrimp determines the ability of phagocytosis. However, haemocyte phagocytosis is reported to be negative correlated with THC after intervention of the disease. Based on this phenomenon it is reasonably suspect that the increase of THC at high density interventions $\left(60,90\right.$ and $\left.120 \mathrm{shrimp} / \mathrm{m}^{2}\right)$ at $24 \mathrm{~h}$, is an attempt to increase the body's defensive ability to fight extreme environmental gradients. Prazzolo et al. (2002) previously reported that one of the Crustacean stragies in response to extreme environments are homeostasis and compensation process for achieving adaptation. Homeostasis and compensation are physiologic responses to normalize an increased heart rhythm due to the presence of space competition and friction between shrimp, this indication can be known because of the increase of THC at $24 \mathrm{~h}$.

The high density interventions (90 and 120 shrimp $/ \mathrm{m}^{2}$ ), if intense up to $36 \mathrm{~h}$, cause tiger prawn juvenile fatigue, resulting in THC decreasing to intolerant levels. This condition triggers to tiger prawn juvenile stressed, which is characterized by depression of silent behavior at the bottom of the tank, no response to objects and feed. Consequently, tiger prawn juveniles did not consumed the feed, less movement and no response at all to disturbance. Selye (1975) reported that although shrimp body has the immune system against stressor, they are unable to continuously maintain their optimum conditions due to energy gradually depleted. Moreover, persistent stress can not be handled through adaptation, and this condition leads to depressive behavior. Furthermore, Kamiso, Tauhid and Coco (2009) reported that a decline in the number of shrimp haemocyte on blood circulation in case of external interference due to supplies of sugar, such as glycogen in the liver is metabolized as energy supplies for the emergency, in this condition, this appetite of shrimp to take food significantly decreased. Similarly, Soelistyowati (2002) stated that the changes of physical, chemical and biological parameter of the environment beyond the optimum threshold and intensively occurs may lead to death due to prolong stress effect. So the 
decreasing number of haemocyte drastically can be used as the indicator of the decline in the defences system. According to Hartinah, La Sennung and Hamal (2014), if tiger prawn are stressed, the percentage the number of hyaline cells decreases from $79-82.66 \times 10^{6}$ cells $/ \mathrm{mL}$ to 42.23-46.16 $\times 10^{6}$ cells $/ \mathrm{mL}$, lower than tiger prawn's hyaline cells (reached $70.2 \times 10^{6}$ cells $/ \mathrm{mL}$ ) cultivated in semi-intensive brackish water ponds (Rustam et al., 2013). It has previously been reported by Hartinah (2012) that an increase in the amount of hemocytes is a homeostasis developed by tiger prawn juvenile in response to extreme environments, Hartinah et al. (2013) suggests that increasing the total hemocytes after attaining adaptation is thought to trigger cannibalism, that the tiger prawn are moulting preyed by other shrimp.

The results of this study also show that THC increases at all tested densities after achieving adaptation. But, tiger prawn juvenile that failed to achieve adaptation to death in the period 24 to $36 \mathrm{~h}$ (homeostasis and compensation period). The dead of tiger prawn juvenile in this period is not expected to reach compensation, this condition indicates that the homeostasis process stops due to intense high density intervention. In the other hand, the tiger prawn juvenile that can live up to 5 days of monitoring period are considered to be able to cope with the stress on the compensation period. Therefore, fatigue presume does not occur, and the tiger prawn is able to adapt the environmental changes. The increase of THC may indicate the juvenile of tiger prawn is successfully adapting to the environmental changes. Moreover, the tiger prawn juvenile is observed more active in the tanks, response to feed and reactive against the foreign object. Tiger prawn juvenile that experience intense stress can cause death, if able to achieve adaptation, then it is died because of cannibalism. Proven feed is available as needed, but cannibalism persists and many feed is left.

The tiger prawns juvenile are stressed, but adaptable, allegedly stress can affect the hormonal activity that triggers moulting. Proven appetite and cannibalism increased. Moulting is an indicator of crustacean growth. Another thing that proves is a lot of dead tiger prawn juvenile prayed by other shrimp after reaching adaptation.

Conducted water quality management during cultivation, so that all environmental parameters, still within the limits can be tolerated by juvenile tiger prawn for survive. The water condition can be maintained because the water change 2 times a day.

Can be concluded that: the tiger prawn juvenile does not stress on the 60 shrimp $/ \mathrm{m}^{2}$ density treatment, but there is pressure that can cause stress at density interventions of 90 and $120 \mathrm{shrimp} / \mathrm{m}^{2}$. Mortality of tiger prawn juvenile that occurs during periods of 24 to $36 \mathrm{~h}$ is caused by stress, while mortality after adaptation (5 days) is caused by cannibalism.

\section{Acknowledgement}

These studies were suppoties by DRPMRISTEK-DIKTI on fundamental research programs, Department of Aquaculture and staff of laboratory seawater hatchery. The outhor whould like to thanks Seniaty, S.Pi.M.Si, Andi Citrawati, S.Pi., and Harianto, S.Pi., for all the help during this study.

\section{References}

Allan, G.L. and G.B. Maguire. 1992. Effects of stocking density on production of Penaeus monodon Fabricius, in model farming ponds. Aquaculture, 107:49 -66.

Buranajitpirom, D.S. Asuvapongpatana, W. Weer achatyanukul, K. Wongprasert, W. Nam wong, P. Poltana, and Bwithyachumnarn kul. 2010. Adaptation of the black tiger prawn, Penaeus monodon, to different salinities through an excretory function of the antennal gland. Cell and Tissue Research, 340(3): 481-489.

Direkbusarakom, S. and Y. Danayadol. 1998. Effect of oxygen depletion on some parameters of the immune system in black tiger prawn (Penaeus monodon). In: T.W. Flagel (ed.), Advances in Shrimp Bio-Technology. National centre for Genetic Engineering and biotechnology, Bangkok, Thailand, pp. 147-150.

Effendie, M.I. 2002. Biologi Perikanan. Yayasan Pustaka Nusatama, Yogyakarta.

Gopinath, R. and K.C. George. 2000. The haemolymph response of Penaeus indicus to the extracellular product of Aeromonas hydrophyla. J.Mar. Biol.Ass.india, 42(1\&2): $84-90$.

Hartinah. 2012. Respon fisiologi juvenil udang windu, Penaeus monodon, Fabricius pada bobot dan densitas pemeliharaan yang berbeda. Thesis dissertation. Hassanuddin University, Makassar, Indonesia

, A. Tahir, M.I. Djawad, and D.D. Tijuno. 2013. Respon seluler juvenil udang windu, Penaeus monodon, Fabricius pada densitas pemeliharaan yang berbeda dalam wadah terkontrol. Jurnal Ilmiah Lutjanus Politani Pangkep, 18:2. 
, L.L. Lasennung, and R Hamal. 2014. Performa jumlah dan differensiasi sel hemosit juvenil udang windu (Penaeus monodon Fabr.) pada pemeliharaan dengan tingkat teknologi budidaya yang berbeda. $J$. Bionature, 15(2):104-110.

Food and Agriculture Organization (FAO). 2006. FAO Fishery Statistics : Cultured Aquatic Species Information Program Penaeus monodon (Fabricius). http://www.fao.org/ fishery/culturedspecies/Penaeus_monodon/en /(January, 2017)

Kamiso, C. Taukhid, and Coco. 2009. Peranan dan Upaya Mensukseskan Produksi Udang Nasional. Direktorat Kesehatan Ikan dan Lingkungan, DKP, Jakarta. dit_kesehatan ikan@dkp.co.id

Lemonnie, H.E. Bernard, E. Boglio, C. Goarant, and J.C. Cohard. 2004. Influence of sediment characteristics on shrimp physiology: $\mathrm{pH}$ as principal effect. Aquaculture, 240(1-4): 297-312.

Lockwood, A.P.M., 1968. Aspects of the Physiology of Crustacea (University Reviews in Biology). Oliver \& Boyd Publisher, London, 328 pp.

Liu C.I. 1989. Shrimp Disease, Prevention and Treatment. In Akiyama D.M. (Ed.). Proceeding of the Southeast Asia Shrimp Farm Management Workshop. America Soybean Association, USA. Pp. $64-74$.

Mangampa, M. Sulaeman, A. Prenrengi and S. Lante. 2008. Optimalisasi tebar benih udang pama (Penaeus semisulcatus) pada pentokolan dengan sistem hapa di tambak. $J$. Riset. Akuakultur, 3(2):175 - 181.

Perazzolo, L.M., R. Gargioni, P. Ogliari, Margherita, and A.A. Barracco. 2002. Evaluation of some hemato-immunological parameters in the shrimp Farfantepenaeus paulensis submitted to environmental and physiological stress. Aquaculture, 214(1-4):19-33.

Primavera, J.H. and F.F. Apud. 1994. Pond culture of sugpo (Penaeus monodon, Fabricius). Philipp. J. Fish, 18(5):14-176.
Re, A.D. and F. Diaz. 2011. Effect of different oxygen concentrations on physiological energetics of blue shrimp (Litopenaeus stylirostris, Stimpson). Open Zoology, 4:1-8.

Rollo A., R. Sulpizio, M. Nardi, S. Silvi, C. Orpianesi, M. Caggiano, A. Cresci, and $O$. Carnevali. 2006. Live microbial feed supplement in aquaculture for improvement of stress tolerance. Fish Physiol. Biochem, 32:167-177.

Rustam, Hartinah, K. Jusoff, S.T. Hadijah, and Ilmiah. 2013. Characteristics of haemolymph's juvenile tiger prawn, Penaeus monodon (Fabricius) reared in ponds. World Applied Sciences Journal, 26: 82-88.

Salama, A.J. 2005. Effect of high salinity water on growth and survival of penaeid postlarvae from the red sea at different stocking densities. Journal of King Abdul Aziz University-Science, 17(1).

Selye. 1975. Kebingungan dan kontroversi di bidang stres. Journal of Human Stress, 1:37 - 44.

Soelistyowati, D.T. 2002. Penyakit Non infeksi, Prekursor dan Penanggulangannya. Aquaculture department, Faculty of Fisheries and Marine Science, Bogor Agricultural University.

Smith, L.S. 1982. Introduction to Fish Fisiology. T.F.H. Publication, Inc., 256 pp.

Supomo. 2009. Manipulasi stocking density dalam budidaya udang putih, Litopenaeus vannamei. Thesis. Lampung University, Indonesia.

Van de Braak, K. 2002. Haemocytic Defence in Black Tiger Prawn (Penaeus monodon). C.B.T. Van de Braak, Wageningen Institute of Animal Sciences, The Netherlands, 159 pp.

Wolffrom,T. 2004. Farmed Fish and Welfare. Direktorate-General for Fisheries, Researh and Scientific Analysis Unit (A4). European Commission. 